\title{
Model Sistem Perubahan dalam Lingkup Program Sarjana
}

\author{
Rinda Cahyana ${ }^{1}$, Irmawati Sagala ${ }^{2}$
}

\begin{abstract}
Abstrak
Sebagai institusi yang memegang peranan strategis dalam transformasi dan pengembangan ilmu pengetahuan dan teknologi, perguruan tinggi dituntut mampu melakukan inovasi-inovasi dalam pengembangan mutu, termasuk dalam hal pemenuhan kebutuhan pembiayaan. Pengelola pendidikan tinggi harus mampu mengembangkan sumber-sumber pendanaan mandiri dengan memanfaatkan sumber daya yang dimilikinya. Dalam konteks inilah, integrasi kegiatan pendidikan/pengajaran, penelitian dan pengabdian kepada masyarakat menjadi alternatif solusi. Produk-produk dari kegiatan tridharma tersebut dapat diarahkan dalam jasa layanan profesi. Paper ini mendiskusikan implementasi model pembelajaran terintegrasi pada jenjang sarjana di perguruan tinggi. Model Daur Hidup yang mengarahkan kegiatan pendidikan dan penelitian untuk diterapkan dalam pengabdian masyarakat yang kemudian akan memberikan umpan balik bagi proses pendidikan dan penelitian berikutnya. Di samping itu, proses ini sekaligus bisa dikembangkan sebagai jasa layanan profesi untuk menjadi sumber pendanaan alternatif perguruan tinggi.
\end{abstract}

Kata Kunci: pembelajaran, perubahan, daur hidup, pendanaan, perguruan tinggi.

\section{Pendahuluan}

Perguruan tinggi yang memiliki kelayakan menurut Peraturan Menteri Riset, Teknologi dan Pendidikan Tinggi (Permen Ristek Dikti) Nomor 32 Tahun 2016 adalah perguruan tinggi yang memenuhi Standar Nasional Pendidikan Tinggi-SNPT. Dengan demikian seluruh aktivitas perguruan tinggi yang dijalankan oleh sivitas akademik harus sejalan dengan standar yang ditetapkan dalam SNPT tersebut. Salah satu aspek yang diatur dalam standar tersebut berkaitan dengan pembelajaran serta layanan profesi dan I atau keahlian.

Menurut Permen Ristek Dikti nomor 44 tahun 2015 tentang SNP, mahasiswa pada program studi sarjana wajib melaksanakan beban belajar paling sedikit 144 SKS (satuan kredit semester) selama maksimum 7 (tujuh) tahun. Termasuk di dalamnya adalah pembelajaran dalam bentuk penelitian dan pengabdian kepada masyarakat yang dilaksanakan di bawah bimbingan dosen. Aktivitas penelitian dilaksanakan dalam rangka meningkatkan kesejahteraan masyarakat dan daya saing bangsa, sementara aktivitas pengabdian kepada masyarakat dilaksanakan dalam rangka memanfaatkan ilmu pengetahuan dan teknologi untuk memajukan kesejahteraan masyarakat dan mencerdaskan kehidupan bangsa (Kemenristekdikti, 2015). Dari kegiatan pembelajaran ini diketahui bahwa perguruan tinggi idealnya merupakan agen perubahan bagi masyarakat dan / atau bangsanya.

Untuk tujuan tersebut diperlukan biaya pendidikan yang dapat diupayakan oleh perguruan tinggi dari sumber internal yang diperoleh dari mahasiswa; dan eksternal dari hibah, jasa layanan profesi dan / atau keahlian, dana lestari dari alumni dan filantropis, dan / atau kerja sama kelembagaan pemerintah dan swasta (Kemenristekdikti, 2015). Dalam konteks ini, penyelenggara perguruan tinggi dituntut memiliki kreativitas dalam pengembangan sumber-sumber pendanaan. Salah satu sumber pendanaan yang layak mendapat perhatian dari penyelenggara perguruan tinggi adalah jasa layanan profesi dan / atau keahlian dengan memanfaatkan produk pengetahuan atau teknologi yang dihasilkan oleh atau digunakan dalam aktivitas pendidikan, penelitian, dan pengabdian kepada masyarakat.

Sangat disayangkan apabila aktivitas pendidikan, penelitian, pengabdian kepada masyarakat, dan jasa layanan profesi dan / atau keahlian tidak saling berkontribusi satu sama lainnya. Produk pendidikan dan
1. Program Studi Informatika Sekolah Tinggi Teknologi Garut, Jl. Mayor Syamsu No. 1 Garut 44151, Indonesia

EMail

rindacahyana@sttgarut.ac.id

2. Program Studi IImu Pemerintahan, UIN Sulthan Thaha Saifuddin Jambi, Jl. Jambi-Ma Bulian Km. 16, Simp. Sungaidurian, Muaro Jambi, Jambi, Indonesia

\section{Submitted : Juli 2017 \\ Accepted : Juli 2017}

FORUM DOSEN INDONESIA 
penelitian skripsi berupa pengetahuan dan teknologi sering kali hanya tersimpan di perpustakaan atau hilang begitu saja. Padahal, produk tersebut dapat diterapkan di tengah masyarakat melalui aktivitas pengabdian kepada masyarakat dan juga dapat dikelola dalam aktivitas jasa layanan profesi dan / atau keahlian dengan memperhatikan hak ciptanya, sehingga diperoleh keuntungan profit yang sebagian di antaranya dapat dialokasikan untuk pengembangan produk berikutnya. Dengan adanya daur hidup produksi pengetahuan dan teknologi serta penerapan atau pemasarannya tersebut, akan menjadikan perguruan tinggi sebagai agen perubahan yang selalu hadir di tengah masyarakat.

Melihat dari pentingnya keterpaduan aspek-aspek tersebut, maka diperlukan model sistem perubahan yang mengandung relasi komponen sistem dengan aktivitas pendidikan, penelitian, pengabdian kepada masyarakat, dan jasa layanan, serta relasi antar aktivitas yang dapat mewujudkan manfaat perubahan berkelanjutan. Artikel ini menjelaskan bagaimana perguruan tinggi dapat berperan terus sebagai agen perubahan di tengah masyarakat melalui kegiatan pendidikan, penelitian, dan pengabdian kepada masyarakat yang saling berhubungan satu sama lainnya; bagaimana perguruan tinggi dapat memanfaatkan produk kegiatannya untuk keperluan layanan gratis dan berbayar dalam rangka mengupayakan dana eksternal; serta apa saja komponen dan aktivitas sistemnya yang diperlukan untuk membangun kapasitas tersebut.

\section{Agen Perubahan}

Kegiatan tridharma, pendidikan/pengajaran, penelitian dan pengabdian ke masyarakat, merupakan aktivitas inti pada Perguruan Tinggi yang akan menempatkan keseluruhan entitasnya sebagai agen perubahan dalam kehidupan masyarakat dan negara. Dengan kata lain, pendidikan tinggi diharapkan mampu menghasilkan karya-karya nyata dalam yang bermanfaat bagi kehidupan manusia, bukan hanya sekedar pengembangan teoritis keilmuan. Tujuan yang ingin dicapai dari penyelenggaraan pendidikan tinggi ini jelas terlihat dalam tujuan pendidikan nasional yang disebutkan dalam pasal 5 Undang-undang Pendidikan Tinggi, yaitu:

1. berkembangnya potensi Mahasiswa agar menjadi manusia yang beriman dan bertakwa kepada Tuhan Yang Maha Esa dan berakhlak mulia, sehat, berilmu, cakap, kreatif, mandiri, terampil, kompeten, dan berbudaya untuk kepentingan bangsa;

2. dihasilkannya lulusan yang menguasai cabang IImu Pengetahuan dan/atau Teknologi untuk memenuhi kepentingan nasional dan peningkatan daya saing bangsa;

3. dihasilkannya IImu Pengetahuan dan Teknologi melalui Penelitian yang memperhatikan dan menerapkan nilai Humaniora agar bermanfaat bagi kemajuan bangsa, serta kemajuan peradaban dan kesejahteraan umat manusia; dan

4. terwujudnya Pengabdian kepada Masyarakat berbasis penalaran dan karya Penelitian yang bermanfaat dalam memajukan kesejahteraan umum dan mencerdaskan kehidupan bangsa.

Baik dosen maupun mahasiswa dituntut terlibat dalam seluruh kegiatan tridharma Perguruan Tinggi dengan memperhatikan sistem tata kelola yang baik (good governance). ${ }^{1}$ Untuk peningkatan mutu dan capaian kegiatan, kegiatan tridharma yang dilakukan mahasiswa perlu disinergikan dengan dosen, dalam sebuah sistem yang terencana. Seorang mahasiswa misalnya, dapat terlibat dalam program pengabdian kepada masyarakat yang dilaksanakan oleh dosen, atau melaksanakannya bersama mahasiswa lain dalam tim di bawah bimbingan dosen dengan berbasis keilmuan melalui kegiatan pengembangan kapasitas masyarakat yang meliputi :

1. Penyadaran dengan menggunakan sumber-sumber pengetahuan;

2. Pelatihan menggunakan teknologi yang relevan; dan

3. Pendampingan untuk memastikan masyarakat dapat menangani kelemahan dan hambatan dalam pemanfaatan teknologi tersebut serta mendapatkan manfaat berupa peningkatan daya saing dan / atau kesejahteraan.

Selanjutnya terkait penelitian, umumnya proses pendidikan yang diikuti oleh mahasiswa program sarjana berujung pada kegiatan penelitian skripsi. Kegiatan tersebut dilaksanakan dengan memperhatikan tubuh pengetahuan, yakni seluruh hasil pengalaman yang diorganisasikan dan disimpan dalam pikiran, buku, makalah, prosiding, laporan dan lain sebagainya (Dawson, 2005). Setidaknya pengembangan yang

${ }^{1}$ Penerapan tata kelola yang baik di perguruan tinggi dikenal juga dengan istilah good university governance (GUG) dengan menerapkan prinsip-prinsip good governance dalam manajemen perguruan tinggi. Lihat misalnya Harsono dan Arina Hidayati. (Desember 2016). Penerapan Tata Kelola Keuangan di Universitas Islam Batik Surakarta Untuk Mewujudkan Good University Governance. Jurnal Pendidikan IImu Sosial, 26 (2), 58-74. 
dilakukan oleh mahasiswa program sarjana dilakukan dalam tubuh pengetahuan kampus, di mana karya penelitian sebelumnya dan sumber pengetahuan kampus lainnya yang relevan dirujuk dengan memperhatikan perkembangan pengetahuan dan teknologi yang ada.

Untuk kepentingan jangka panjang, peta jalan penelitian perlu dibuat oleh dosen agar pengetahuan atau teknologi dapat dikembangkan oleh dosen secara berkelanjutan dan mengarah pada tujuan spesifik. Peta jalan menggambarkan tonggak yang harus dicapai dalam periode tertentu untuk mewujudkan tujuan peningkatan kesejahteraan masyarakat dan daya saing bangsa dengan memanfaatkan produk penelitian berupa pengetahuan dan / atau teknologi. Produk tersebut terus dikembangkan di sepanjang jalan penelitiannya. Dalam peta penelitian inilah, dosen dapat mengikutsertakan mahasiswa bimbingannya untuk melakukan sebagian kecil kerja penelitiannya, disesuaikan dengan kemampuan atau jenjang pendidikan mahasiswanya. Dengan demikian, baik dosen ataupun mahasiswa mewakili perguruan tingginya menjadi agen perubahan bagi masyarakat dan bangsanya.

Meskipun masing-masing memiliki domain berbeda, namun pada prinsipnya ketiga unsur tridharma memiliki keterkaitan yang saling mendukung dalam mencapai tujuan dan menghasilkan luaran yang berkualitas. Keterkaitan antar unsur tersebut dapat membentuk sebuah daur yang berulang dan dinamis. Pengetahuan dan teknologi yang diterapkan dalam kegiatan pengabdian kepada masyarakat diharapkan merupakan hasil dari beragam bentuk pembelajaran seperti kuliah, responsi, tutorial, seminar, praktik dan penelitian sebelumnya. Dari aktivitas pengabdian kepada masyarakat, mahasiswa dan dosen pembimbingnya kemudian dapat melihat ruang masalah baru yang belum diketahui solusinya, dan dapat ditindaklanjuti oleh penelitian dan kegiatan pembelajaran lainnya. Proses daur ini ditunjukkan dalam gambar berikut:



Gambar 1. Daur sinegisitas kegiatan tridharma perguruan tinggi

Melalui model tersebut, seluruh aspek tridharma perguruan tinggi membangun kesatuan proses yang saling bersinergi dan didesain jangka panjang. Dengan demikian, pengukuran pencapaian target-target atau realisasi visi dapat diukur dengan jelas secara periodik, dan dengan sendirinya dapat dievaluasi capaian tujuan pendidikan di perguruan tinggi sebagaimana disebutkan di atas.

\section{Jasa Layanan Berbayar}

Jasa layanan profesi dan / atau keahlian dapat diselenggarakan dengan modal pengetahuan dan teknologi yang merupakan produk pendidikan, penelitian, dan pengabdian kepada masyarakat. Saat ini, pemanfaatan produk perguruan tinggi kepada masyarakat yang dikembangkan secara luas baru mencakup kegiatan non profit melalui aktivitas pengabdian kepada masyarakat yang dilaksanakan secara sukarela. Lain halnya dengan jasa layanan profesi dan / atau keahlian, produk tersebut disampaikan kepada masyarakat dengan tujuan profit. Hal tersebut boleh dilakukan oleh badan penyelenggara perguruan tinggi dalam rangka mengupayakan pendanaan di luar biaya pendidikan. Dengan demikian, mitra perguruan tinggi mendapatkan pengetahuan atau teknologi secara berbayar atau gratis, dan semuanya dimaksudkan untuk mengubah kondisi masyarakat dan / atau bangsa.

Kegiatan jasa layanan profesi dan / atau keahlian ini setidaknya memiliki tiga nilai strategis. Pertama, sebagai pemenuhan kebutuhan dana penyelenggaraan pendidikan. Fakta menunjukkan bahwa kemampuan finansial rerata perguruan tinggi di Indonesia masih lemah, bahkan meskipun sudah dimulai afirmasi anggaran 20\% untuk pendidikan. Kedua, jenis kegiatan ini akan mendorong perguruan tinggi lebih menggali dan memberdayakan potensi internalnya. Meskipun sumber pendanaan luar, terutama 
dari lembaga donor luar negeri, memiliki kesan lebih bergengsi (Halloway, 2001), namun optimalisasi potensi internal memiliki nilai strategis yang sama (Sakarya, 2014). Kemandirian internal akan berdampak pada peningkatan kepercayaan diri dan independensi perguruan tinggi. Ketiga, model ini juga akan menghasilkan multiple effect terhadap perguruan tinggi baik terhadap institusi maupun sumber daya manusianya.

Secara keseluruhan, kegiatan jasa layanan profesi dan / atau keahlian dirancang sebagai satu kesatuan dengan daur pembelajaran yang telah dibahas sebelumnya. Penyelenggaraan kegiatan ini merupakan hasil dari kegiatan pendidikan dan penelitian, dan seperti halnya pengabdian kepada masyarakat dapat kembali memberikan umpan balik bagi kegiatan pendidikan dan penelitian selanjutnya. Daur sinergi kegiatan jasa layanan profesi dan / atau keahlian ditunjukkan dalam gambar berikut ini:

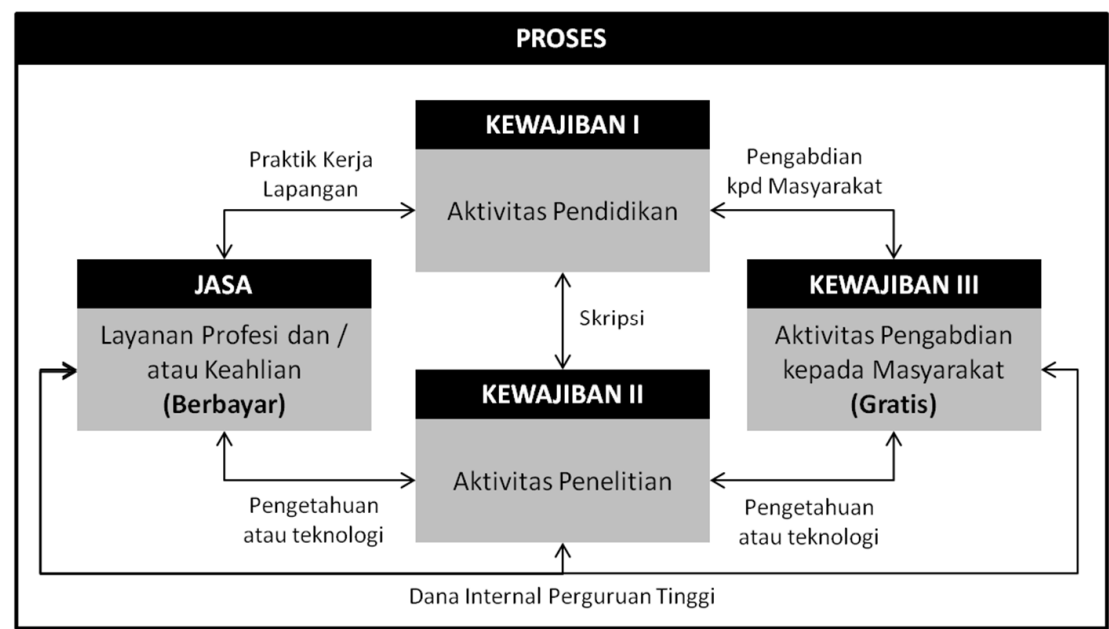

Gambar 2. Daur sinergi kegiatan jasa layanan profesi dan / atau keahlian

Permasalahannya kemudian adalah penentuan mana produk yang patut dijadikan layanan berbayar. Untuk menjelaskan masalah ini, kita ambil contoh dalam pendidikan tinggi bidang teknologi informasi. Perguruan tinggi dalam domain ini dapat menyelenggarakan kegiatan penyadaran dan pelatihan menguasai teknologi pada level dasar bagi mitra secara gratis melalui program pengabdian kepada masyarakat yang dijalankan oleh unit kerja atau tim penelitian dan pengabdian kepada masyarakat. Sementara penguasaan teknologi pada level lanjutan yang berbayar dilaksanakan oleh unit bisnis perguruan tinggi yang menjalankan jasa layanan profesi dan / atau keahlian. Sebagian keuntungan dari Jasa layanan profit tersebut dapat dialokasikan sebagai dana pembiayaan internal. Menurut Permen Ristek Dikti nomor 44 tahun 2015 tentang SNPT, dana internal tersebut digunakan untuk membiayai perencanaan, pelaksanaan, pengendalian, pemantauan dan evaluasi, pelaporan dan diseminasi hasil penelitian dan pengabdian kepada masyarakat (Kemenristekdikti, 2015), baik seluruhnya atau sebagian.

Untuk peningkatan profesionalisme pengelolaan jasa layanan profesi dan / atau keahlian ini, dapat dibentuk koperasi atau badan usaha milik perguruan tinggi yang diatur kebijakan, mekanisme, dan prosedurnya oleh perguruan tinggi agar tercapai akuntabilitas dan transparansi. Pembentukan koperasi juga akan melahirkan multiple effect bagi perguruan tinggi. Mahasiswa, misalnya, dapat ikut terlibat dalam pekerjaan unit bisnis tersebut melalui praktik kerja lapangan. Unit bisnis tersebut dapat menjadi tempat kerja sementara atau tetap bagi lulusan perguruan tinggi, sehingga perguruan tinggi tidak hanya meluluskan sarjana tetapi juga menyediakan lapangan kerja bagi mereka. Unit bisnis ini dapat digunakan oleh program studi atau unit kerja khusus terkait pengembangan karier untuk menganalisis kapasitas kompetensi mahasiswa. Pengukuran ini penting mengingat lulusan program sarjana sekarang ini menurut SNPT harus mendapatkan pengakuan atas keterampilan khusus, yakni kemampuan kerja sesuai dengan bidang keilmuan program studinya. Pengakuan tersebut berwujud sertifikat kompetensi yang diperolehnya bersama dengan ijazah, gelar, dan surat keterangan pendamping ijazah (Kemenristekdikti, 2015).

\section{Komponen dan Aktivitas Sistem Perubahan}

Model sistem perubahan menggambarkan keseluruhan aktivitas dan komponen sistem yang digunakan untuk membuat perubahan secara berkelanjutan. Keluaran dari proses (aktivitas tridharma dan jasa 
layanan) dimanfaatkan terus menerus oleh agen perubahan di bawah kendali, dengan mengikuti peta jalan penelitian, serta memperhatikan data permasalahan dan data terkait pengetahuan dan teknologi yang ada / legacy. Sistem ini memberikan kesempatan bagi perguruan tinggi untuk memutarkan dana dari dan untuk aktivitas tridharma, sehingga harapannya bukan hanya terjadi peningkatan produknya dan dampaknya saja, tetapi juga peningkatan pendapatan jasa layanan. Ketersediaan dana eksternal dari jasa layanan ini memberi perubahan bagi masyarakat internal dan eksternal perguruan tinggi.

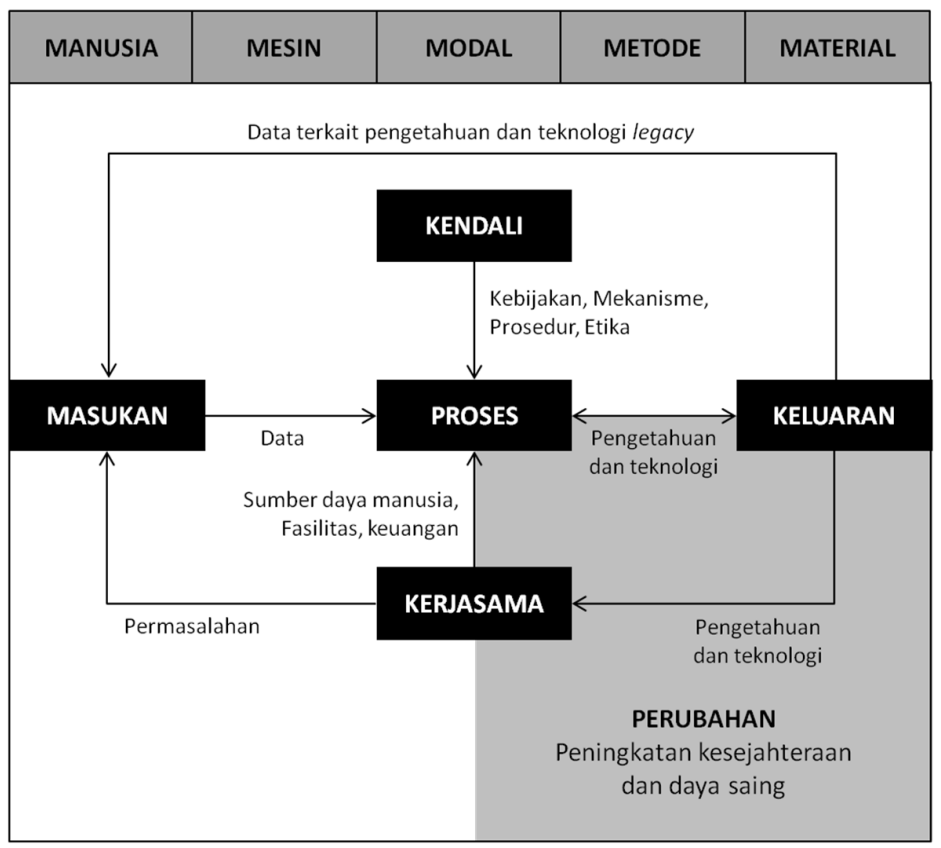

Gambar 3. Model Sistem Perubahan

Aktivitas sistem perubahan meliputi :

1. Aktivitas kerja sama yang digunakan oleh perguruan tinggi untuk mendapatkan sumber daya manusia, fasilitas, dan keuangan yang dibagi, serta akses ke permasalahan nyata;

2. Aktivitas pemasukan data yang bersumber dari mitra atau sumber-sumber pengetahuan dan teknologi legacy;

3. Aktivitas proses produksi pengetahuan dan teknologi dengan berdasarkan data tersebut, menggunakan komponen sistem internal dan eksternal;

4. Aktivitas kendali menggunakan produk kebijakan, mekanisme, prosedur, dan etika untuk memastikan sistem berjalan sesuai dengan rencana strategis perguruan tinggi; dan

5. Aktivitas keluaran berupa penerbitan atau distribusi produk dalam beragam bentuk media seperti software-suite, buku, makalah, prosiding, laporan dan lain sebagainya.

Dengan demikian faktor produksi utama yang diperlukan untuk menjalankan proses sudah dipetakan yang meliputi :

1. Manusia, yakni pengampu kewajiban pendidikan, penelitian, dan pengabdian kepada masyarakat (dosen, mahasiswa), pengendali sistem (pengawas dari unit atau lembaga terkait di perguruan tinggi), penerima manfaat (mitra perguruan tinggi dari badan publik, badan usaha, dan komunitas);

2. Mesin, yakni teknologi atau fasilitas lainnya milik perguruan tinggi atau mitra, termasuk yang dihasilkan oleh sistem perubahan internal atau eksternal perguruan tinggi;

3. Modal, yakni dana yang bersumber dari internal atau eksternal perguruan tinggi, termasuk yang dihasilkan oleh sistem perubahan internal perguruan tinggi;

4. Metode, yakni produk kebijakan, mekanisme, prosedur, dan etika terkait sistem perubahan; dan

5. Material, yakni data permasalahan dari mitra atau data terkait pengetahuan dan teknologi legacy produk sistem perubahan internal atau eksternal perguruan tinggi.

Seluruh faktor harus dikelola secara seimbang dengan berbasis pengetahuan ilmiah agar menghasilkan capaian yang memenuhi tujuan sebagaimana telah ditetapkan di awal. 
Penutup

Optimalisasi pencapaian tujuan pendidikan tinggi akan dicapai dengan menerapkan model daur sinergi kegiatan tridharma pendidikan tinggi yang terencana dalam jangka panjang. Model pembelajaran daur sinergi ini juga akan membuka peluang pengembangan jasa layanan profesi yang merupakan salah satu alternatif sumber pendanaan kreatif perguruan tinggi. Sumber pendanaan yang memanfaatkan sumber daya internal seperti ini selain akan membantu peningkatan mutu penyelenggaraan pendidikan tinggi juga sekaligus meningkatkan mutu luaran yaitu lulusan. Penyelenggaraan jasa layanan profesi akan menjadi sarana aplikasi pendidikan entrepreneurship di perguruan tinggi dan lebih jauh dapat ditindaklanjuti dalam pengembangan dunia usaha pasca kampus para lulusan.

Pelaksanaan daur sinergi kegiatan tridharma dan jasa layanan profesi dan / atau keahlian dalam model perubahan harus dikelola dengan memanfaatkan seluruh sumber daya yang dibutuhkan secara profesional baik menyangkut hardware maupun software. Keberhasilan proses ini ditentukan oleh sejauh mana proses manajemen dapat dilakukan dengan baik melalui sistem yang terintegrasi dalam masingmasing perguruan tinggi.

\section{Daftar Pustaka}

Cahyana, R. (2014). The stages, three-layer infrastructure, and functional level regulation for development of information society within of information technology volunteer actions. International Journal of Basic and Applied Science, 3(1), 28-35.

Dawson, W. C. (2005). Project in Computing and Information System : a Student Guide. England: Pearson Education Limited.

Harsono dan Arina Hidayati. (Desember 2016). Penerapan Tata Kelola Keuangan di Universitas Islam Batik Surakarta Untuk Mewujudkan Good University Governance. Jurnal Pendidikan IImu Sosial, 26 (2), 58-74.

Holloway, Richard. (2001). Menuju Kemandirian Keuangan. Jakarta: Buku Obor.

Kemenristekdikti. (2015). Permen Ristekdikti no 44 tahun 2015 tentang Standar Nasional Pendidikan Tinggi. Jakarta, Indonesia.

Kemenristekdikti. (2016). Permen Ristekdikti nomor 32 tahun 2016 tentang Pedoman Akreditasi Perguruan Tinggi dan Program Studi. Jakarta, Indonesia.

Sakarya, Arif Orcun. (2014). Examination of Innovation Sources and Cooperation Alternatives for Turkish Firms. Eurasian Journal of Business and Management, 2(1), 36-45.

Undang-undang Republik Indonesia No. 12 Tahun 2012 tentang Pendidikan Tinggi. 